\title{
Experiencing Folk Music in Children
}

Konstanca Zalar

University of Ljubljana, Faculty od Education, Department of Music

\section{Abstract}

Through everyday exposure to language and music, individuals within a nation become sensitive to the melodic and rhythmical structure of their folk musical culture. It represents improvisational abilities of individuals and groups as well. Despite all changes, it indisputably maintains all characteristics of music parameters as inheritance of past ages. Due to its social role, it appears throughout everyone's life - and it also represents an important part of children's life. In the study that was carried out with two groups of children between six and nine years of age, we were interested in determining how children experience music making with elements of folk music and how it is possible to create the circumstances which can provide the spontaneity of folk music within the structured environment (like primary school). The research was designed as a phenomenological case study. This method allowed us to gather data which provided a deeper insight into the ways in which participants are able to play using elements of folk music and the way they feel while using such material. The results show that, contrary to the basic fact of spontaneity in folk music, 6 and 7 year old participants were not able to use music parameters to play with and had yet to learn how symbolic play works out in musical language on the basis of communication. The most natural way to bridge the gap between "learning" songs and experiencing individual musical expression in a manner of folk music in children seems to be creative work with lyrics in Slovene language. We also found that children develop social competences of a great value, when they are involved in symbolic play with folk music elements in the improvisational mode.

Key words: folk music; improvisation; music language; music making

\section{Introduction}

Music plays a significant role in the socialisation process of imparting desired values, attitudes and behaviours as children progress through various stages of life (Kalinde, 
2016) - especially, every nation's folk music lives in a situation characterised by internal connections between its people and their cultural heritage. It is a sincere expression of people's experience and as such developed in everyday and festive occasions: it consoled baby's cry in the cradle, paid nocturnal visits to girls, addressing them from beneath their bedroom windows, rejoiced in dancing, celebrated at weddings, mourned at catafalques, "laughed loudly to conceal tears ..." (Cankar, 2012, p. 21). It evolved as an expression of sensations in a spontaneous use of musical parameters and, in every nation, developed different characteristics in the sense of rhythm, meter, form, length and structure of verses, tonality, singing technique, the number of singing parts and relationships between them, etc. (Kumer, 1975, 1977; Kunaver et al., 1987). The source of folk music is the ability of folk singers and instrumentalists to improvise. They produce music without consciously and intentionally shaping it, yet it is consistent in its form and content.

Children's folk songs represent an equal and extensive part of the folk heritage. They include songs children sing themselves and also those sung to them by adults. The contents reflect the environment in which they are created: contact with nature, animals, etc. In the urban environment, they can be inspired by the world of technology (Kumer, 1975). They also evolve spontaneously out of an inner need to express oneself. Many studies (Biber, 2016; Chronopoulou \& Riga, 2012; Frid et al., 2016; Han et al., 2003; Howard-Jones et al., 2002; Kiehn, 2003, 2007; MacDonald et al., 2006; Morin, 2001; Niland, 2009; Russ et al., 1999; Soley \& Spelke, 2016; Sternberg, 2006; Tarnowski, 1999) prove that such a creative approach in children occurs automatically, and, in particular, highlight the positive influence on the common or individual improvisational motivation within the concept of flow in play. All these characteristics - together with improvisation and composition - are pursued by the Slovene curriculum for music education in primary school (Učni načrt za glasbeno vzgojo vosnovni šoli, 2011), which establishes educational objectives in the sense of holistic teaching and defines music as a "cultural phenomenon" (ib., p. 39) and as "an individual's need for an organised acoustic environment, sound-based communication and creativity" (ib.). Thus, the elements of the Slovene folk music are incorporated in the school environment in the way that through creating, performing and listening activities, students acquire the musical experience necessary to deepen their apprehension of and preserve their interest in music, as well as strengthen their curiosity for "the surprises springing up from music itself" (ib., p. 15).

\section{Research}

\section{The purpose of the study}

In the study, we were mainly interested in the use of the inventive capability regarding the use of folk music parameters in 6 to 9 year old children. We were searching for folk music elements as a way of communication in a school environment and possibilities for the playful use of these elements. Our presumption was that the pursuance of 
folk music in young children must surpass the mere reproduction and include the elements of creative expression. Therefore, we considered music making in folk manner as improvisation and formed a holistic music education environment by including "Orff-Schulwerk" approach with body percussion and whole-body movements, using voice to create individual sounds and singing, playing children's and improvised instruments, and encouraging listening carefully to oneself and to the way in which one's own performance is placed among that of other participants. We looked at how children, with their fluency and suppleness of mind in the imaginative process, deal with individual musical elements to create their own music language.

\section{Research questions}

On the basis of the research objective, the following two research questions were formed:

- how do children experience music making with elements of folk music,

- how to create the circumstances, which can provide the spontaneity of folk music within the structured environment (like primary school).

\section{Methodology}

The research was designed as a phenomenological case study. Its main characteristic is that it goes into profound details of systematic exploration and vivid describing of the manner of establishing the connections among all participants (Kordeš, 2008, 2009; Yin, 2004). This is why the research method enabled us to observe the participating children directly during music lessons and examine how individuals behaved and expressed when they were performing Slovene folk songs and playing with the elements of folk music. Thus, it was also possible to monitor relations among participants while they were playing with different folk music parameters and describe non-verbal communication, which occurred during the lessons.

The study was carried out over a nine-month period in an urban primary school. We carried out 52 lessons with two groups of children. All together there were 29 participants involved, 17 of which were girls and 12 boys between the age of 6 and 9 . Ten children of the second group ( 8 and 9 year old participants) were already involved in a preliminary study two years ago.

Table 1

The structure of participants

\begin{tabular}{lccc}
\hline Group & Girls & Boys & Together \\
\hline 1st group (6 and 7 year old) & 10 & 7 & 17 \\
2nd group (8 and 9 year old) & 7 & 5 & 12 \\
Together & 17 & 12 & 29 \\
\hline
\end{tabular}

We decided to observe younger children since we presupposed that, due to their young age, they would be able to feel unperturbed and enthused at the same time in symbolic play. In the holistic approach to music education (such as "Orff-Schulwerk"), 
this play could be represented by other, non-musical phenomena, e.g. "translation" of an image, event or narrative into a larger music event (Sangiorgio \& Henessy, 2013) in the same way as folk music is created and as it functions.

During the lessons, data were gathered in two Protocols with Descriptive Notes (Descriptive Protocol) and Reflective Notes (Reflective Protocol). As the teacher was simultaneously also the researcher (the author of this article), the techniques of overt participant observation was used. By using this technique we were able to watch the participants experience fields while they were playing with the elements of children's folk music, and to identify the circumstances of their music making. The Descriptive Protocol included the descriptions of the happening $(\mathrm{DH})$ which were written down directly after each lesson from the teacher's memory. Since such data cannot be completely reliable and objective, all lessons were also video recorded. This enabled us to reach the moments of play, which the teacher was unable to describe because of her own involvement in these activities. Based on the transcriptions of the recordings, the use of folk music elements (ME) was recorded in the Descriptive Protocol: the outlines of the rhythmic elements (MEr), the melodic contour (MEm), the use of dynamics (MEd) and articulation (MEa), as well as the creation and use of lyrics in connection with the melody $(\mathrm{MEl})$. In order to better understand the meaning children gave to the created music, the transcriptions of their speech (CS) in the final discussions were also included in the Descriptive Protocol.

The Reflective Protocol (RP) was created as part for comments and clarification about the process - activities in the groups summing up the decisions for later theme development.

\section{Definition of Categories}

The data gathered in the Descriptive Protocol were shown in the form of a timeline, which showed the sequence of individual lessons (e.g. L1, L2, etc.) and coding units (e.g. L1/1, L1/2, etc.). In the qualitative data analysis, the final relational coding was obtained through open and axial coding. Out of the seven defined categories, three appear to be relevant for explaining the manner of children's experiencing Slovene folk music elements and describing the circumstances which enabled the children to express themselves in its distinctive spontaneity within the structered enviroment in primary school.

\section{Answering to Musical Stimuli}

This category expresses the responses to musical stimuli which children demonstrated during the lessons. The records in our data show a high level of participants' commitment in the communicative aspect of music. This could be found out during group activity: "Darij got upset when we were listening to a recording... and he had a row with... We interrupted the lesson and solved the problem verbally" (DH, L19/2); or - and especially in discourses which followed the performances. We also observed their facial expressions: 
"Children are smiling again and again when..." (DH, L58/3). The participating children assessed the singing or playing of others. Their assessments were honest and even humorous: "Wow, what a great suggestion of yours!"(CS, L33/6) and "Your performance wasn't gentle at all. I thought it would sound softer" (CS, L12/6). Towards the conclusion of the study, after having been given the topic (from the children's folk heritage) of a lesson, children themselves looked for musical elements to explore during the lesson. In many cases, the materials indicated the use of music to explain non-musical contents: "Jan plays the large cymbal resolutely, which indicates the beginning of the performance" ( $\mathrm{DH}$ MEa, 32/4); "A small group of children is running around on their tiptoes. Another group is accompanying their movement by drumming their fingernails on the floor or wooden objects. With very serious expressions on their faces and making large movements with their arms, the rest of the children are preparing to take 'the stage' and play the drums" (DH - MEr, $\mathrm{MEa}, \mathrm{L} 32 / 6)$. The invention sung by a talented girl named Liza, who reached a high level of improvisational performing practice, has a special place in the materials. She sang a relatively long melody in rubato in the Dorian mode (DH - MEm). We presume that the girl did not know any melodies in the Dorian mode beforehand (children are familiar with melodies in major and only rarely also in minor), and that she sang her invention that way, because "she was empathically related with her school mates during the creative activity and expressed her inner experience that way. Her performance got the total attention of other children who stopped and listened to her attentively" (DH, L34/5). Other children's singing inventions were less stable in terms of tonality, since nobody else sang their inventions within a certain scale (not even major or minor). However, their improvised singing unquestionably reached the sensations of their schoolmates who listened carefully and with interest (DH). Everybody also used made-up lyrics, either in non-rhymed, longer narrative forms, or in the form of shorter rhyming couplets explaining mostly the actions during the lessons (DH).

\section{Conception of Music Language}

Within this category, we described a range of key descriptions from our data reflecting the manner in which the participating children learned about the potential ways of communicating in musical language through improvisation. During the initial, experimental lessons, it was not possible to notice any improvisation elements characteristic of folk music. Children favoured learning rhythmic and melodic contents by imitation, rather than including them into spontaneous play. "Children endeavour to make fun in their own way, since they do not comprehend my non-verbal communication as a request to musical play," $(\mathrm{DH}, \mathrm{L} 2 / 8)$ the teacher wrote. Later it was possible to detect that children passed from plays governed by rules to playing rhythmic and rhythmicmelodic questions and answers (call-and-response format), showing a high level of musical abilities and skills. "Children repeat rhythmic and melodic questions correctly and reliably, and they are also able to use them as answers. Thus, they form a (too) long chain of the same rhythmic-melodic motives, which seems to be more and more uninteresting to 
them" (DH, L3, L4). "What's going on now, aren't we going to learn anything new?" (CS, L4/3) asked Jakob. His question made other children realise they could change the motives, which they did right away, but only by using different original articulations and dynamic nuances, and not by changing the pitch or duration of tones. Nonetheless, the fact that children changed the character of the content provided by the teacher meant that the field of individual expression started to open gradually. After at least 15 lessons in a group of 6 and 7 year old and at least 10 lessons in a group of 8 and 9 year old, children started to take pleasure in the exercise. A play with music elements started to grow up. Children's sang folk tunes, rhythmicised texts, used children's musical instruments and they feel free to use body movements as part of the play. Later, they re-shaped the performed musical material, expanded it and developed smaller or bigger forms of a sound story - they created sounded story telling. This process is registered in conversations: "Why did you play as silently as a new born puppy?" (CS MEd, L39/4), "You didn't answer correctly: you were too fast, faster than me." (CS - MEr, L7/6), "Your playing was very dwarf alike; it was completely spun out of control." (CS - MEa, L19/8), "Your first tone was higher, but the second was 'looooonger' and so low. It sounded so strange to me." (CS - MEm, L27/12), and in the movement of their whole bodies or (only) in the movement of hands as well (DH). The way in which children led each other to replicate or add to the motives was very convincing. A relaxed symbolic play progressively led to the point where the first musical motive "disappeared" and was replaced by new motives - the result of short inventions by individual participants. These new motives retained the same structure and tonality as the songs children knew from their broader environment, but they had a completely different character. Besides, they were not created as a response to a certain musical inducement, but represented a certain impression, environment, event, plot, etc. Children spontaneously used various objects as improvised musical instruments, included movement in their performance and verbally reported about what they had experienced: "I got a little thrilled and anxious, because you didn't stop shouting 'toooo toooo'loudly, then I was okay again and I was able to continue playing on" (CS, L44/9).

The category "Conception of music Language" is strongly related to data which characterize the elements of the inventive process, which enabled children to make a musical product by using the rhythmical elements in connection with invented lyrics. As it is evident, it was much easier for the participants to play with rhythmical contents than with melodic ones, and it was in rhythm that they showed up a substantial capability to improvise. The participants in both groups were entirely successful in inventing new lyrics to known melodies. They created lyrics for short three-tone exclamations, as well as for two-, four- or eight-bar long melodies. The accents were in line with the metric structure of the melody, e.g. "Kdo si ti, kdo sem jaz? Vsi poglejte moj obraz." (Who are you, who am I? All of you look at my face.) (CS - MEr, L44/6). The lyrics were mainly in the form of couplets, with a certain metric structure - in most cases trochaic hexameter or trochaic heptameter (as in the example above), 
which is characteristic of Slovene (children's) folk song. In a more and more relaxed symbolic play with musical parameters and in line with language syntax, children were "threading" new verses, building on a given pre-existing folk text, e.g. "Ko sem $k$ njej pršou, mi je dala stol" (When to her I came, she handed me a chair) (Kumer, 1975). What followed evolved (with a help of a very big linen picture of a scene in nature, which was drawn by participants in several previous lessons) into a proper story from everyday life, with strong awareness of rhyme on one hand: "Ko sem tuki šel naprej, sem si tkole reku zdej: nč se ne bom bal, bom pogum nabral." (While walking forward here I said to myself: I won't be scared, I'm gonna 'pick up' the courage.) (CS - MEr, L44/12), and, as an early step towards an entirely free shaping of the music material: "Kok me tuki zebe zdej, ojoj..., kaj vse se tle dogaja ..." (I'm so cold here, oh my ..., what's going on here ..." (CS - MEr, L44/12). This meant a transition to the creation of a sounded story telling with a various use of voices, improvised instruments, gestures, mimics, simple objects, etc. The participants often added interludes played on improvised instruments between the sung verses (mostly four-bar melodies). These interludes stepped out of the meter of the verses into a rubato and were, with their specific sound, an expression of the participants' own interpretation (DH). During the lessons towards the end of the (preliminary) study, this kind of work formed a clear rondo form with a metrical part $\mathrm{A}$, rhythmically free part $\mathrm{B}$, which included the pronunciation of individual syllables and sounds in many different ways, a singing part $C$ (in which children sang a familiar melody) and part $\mathrm{D}$, in which the motor expression from all previous parts was joined by rhythmic instruments as the core of the newly created sound story. In some of the improvised parts of the rondo, non-verbal communication in musical language took place, clearly representing different musical sensations of all participants and leading to successful symbolic playing in a group improvisation. An accurate perception of rhythm as the core musical parameter in improvisation was also evident in duets. "While Ana was singing her improvisation in a narrative rubato, Sanja was accompanying her with twigs from the forest. She 'caught' the accents of her words which she pronounced with different speeds and long breaths in between, during which she had the time to observe her schoolmates and study their reactions, adapting her following routine appropriately" (DH, L44).

\section{Constructing Social Relations}

The category includes descriptions of those moments of participants' non-verbal communication in music, where we noticed empathic sensations occurring in a group improvisation. Coding and categorising these descriptions required the utmost attention, since all activities in the form of symbolic play are filled with participants' sensations, as everybody feels something at any point of an activity. Therefore, the descriptions in the Protocol report about the progress of individual participants in a common activity when it was possible to notice such sensations from their facial expressions, the way they approached their school mates, their contributions to the 
common sound story or sounded story telling (and definitely not from their verbal reports) and from the expression of these sensations through languages of other arts (DH). The upsetting factor for the engagement in improvisation or non-verbal communication in musical language was the confidence of a girl named Roza ( 9 year old) in her own musical abilities. She covered up the actual state by criticising others, as if they were disturbing: "You played this wrong again. / Come on!" (CS). Thus, she was preventing herself to become part of common activities, and, by the end of the school year, she did not manage to grasp the common work - improvisation in folk music, which others engaged in (DH). As it was obvious during several following lessons, the fragility of children's attention made it very difficult to create a "music-making" environment and this required considerable effort from children as well as the teacher. Natural instruments proved to be an efficient help. They attracted children's attention and drew them into the exploration of sounds, and thus also into the awareness of individual musical parameters (DH), carrying them closer to the sound and way of performing children's folk music.

\section{Grounded theory}

The procedure of relational coding led to the formulation of the following three findings in grounded theory:

6 and 7 year old participants were not able to use music parameters to play with and had yet to learn how the symbolic play works out in musical language on the basis of communication.

Discomfort in learning about the content of musical language and about communication in music language in improvisation revealed that children in the first group (age 6 and 7) were not familiar with this way of communicating. Even though performance of children's folk music is typically unplanned and occurs in a relaxed atmosphere while socialising with peers, and despite the fact that all participants had relatively high musical skills and abilities, there were some difficulties regarding the way relationships between participants in musical communication were arranged. However, in some situations of recognising musical parameters it was evident that folk music, together with short children's lyrics, can influence significantly the development of general abilities of associating with others in the non-verbal musical language. In this respect, the findings of the study showed that the play with musical elements developed in a different order than the one usually claimed by developmental psychology, i.e. that naturally, sensorimotor play occurs first, and is followed by symbolic play and rulebased play (Papalia et al., 2003; Sangiorgio, 2010). In our case, the development of musical play started with rules: children were asking "What is correct?" and wanted instructions for "solving" the given tasks. Then, even though they were only six and seven years old, all participants started exploring their own voice, instruments as soundproducing objects, including body percussion, etc. (the sensorimotor stage of play). Over several months, they "learned" to play by using their imagination, imitating and 
creating in musical language. This symbolic play is the foundation of holistic music education. It gives children a path deep into the music, enables them to create and imagine it and play with it. Play as improvisation is also a central factor in Orff Music Therapy, although activities in spontaneous play as well as making music do not make any difference dealing with persons with special needs or others. G. Orff (1989) claims that improvisation serves to offer a creative stimulus for every child and can provide structure just through sound and silence and offer children the possibility to explore and investigate, to put together sounds or objects, to "practice" by playing and to form associations. The most common goal is the development of interactive competences - competences which enable the participants to interact with persons and objects in their environment (Voigt, 2003).

Similarly, Orff (in Jungmair, 2003, p. 193) described the development of communication in musical language as "a path, which leads from the initial confusion in learning about oneself to an inner security." Other educational theoreticians also report about the positive effects of the described learning path. Medveš (2007) claims that lessons are educative when they have logically established stages, which contribute considerably to the internalisation of values, and, finally, to the development of personality. According to Kroflič (2007), approaching a goal, with certainty and selfconfidence preventing inappropriate influences, is an important educational feature which can be connected to the development of play with elements of folk music, as described above. The elements of relational pedagogy, which support the development of empathic sensations and operation, also lean towards this objective. They point to interpersonal relations, which exist in common activities and beyond, claiming that teaching is about building educative relations. As a result of the study, it is possible to confirm that the positive shift in children's attitude towards their communication in symbolic play and the ability to cooperate in group improvisation are in line with the principles of the relational theory.

The most natural way to bridge the gap between "learning" songs and experiencing individual musical expression in a manner of folk music in children seems to be a creative work with lyrics in Slovene language.

Rhythmical contents were the first typical element of musical syntax where the participants demonstrated their abilities of creating - improvising. There were short texts, which children made up to a known melody, or rhythmical answers to a given question. At first, children considered these activities as schoolwork. It was only after several months when they felt so comfortable making up texts that they included them in symbolic play. Initially, they articulated texts in line with the characteristics of the Slovene folk music, i.e. strictly syllabically, stressing the syllables according to the rules of their mother tongue. Thus, they confirmed the presumption of a study (Iversen et al., 2007) claiming that organising the smallest rhythmical patterns into larger units is an innate characteristic of auditory perception in all cultural environments. This means 
that mother tongue influences the auditory perception in general. The perception of speech with its rhythmic structures forms a channel through which mother tongue also influences the perception and performance of music. All these findings are confirmed in a research (Linnvalli et al., 2018) which suggests that intensive musical training enhances children's linguistic skills. By comparing the development of music playschool children to their peers either attending to similarly organized dance lessons or not attending to either activity the authors proved that music playschool significantly improves the development of children's phoneme processing and vocabulary skills. Also, Leman (2007) claims that spontaneous movement to music appears to be strongly connected to predictions of local burst of energy in the audio stream, such as beat and rhythms. He introduced three ${ }^{1}$ stages, which presumably influence physical articulation in music-induced movement. Empathy is the third of them and is important for linking musical features to emotions and expressivity.

The participating children in our study connected the characteristics of sentence phonetics and musical language, e.g. in a rhythmical question (including the sung questions), they made the durations of tones shorter, even on the last beat of the question. It was possible to perceive this as a special tension. On the other hand, the durations in the answers became longer and longer towards the end, creating a sense of calmness. By using sound formation, rhymes and alliterations, children came close to the abstract expression of sensations and communication in musical language without meaningful words and developed phonological awareness.

In the study, those participants who did not wish or manage to reach an even musical pulse (meter) in their initial performances engaged more deeply and with greater emphatic sensations in the musical communication with others. They demonstrated unusual and original uses of all musical parameters and wanted to express their experience through other arts. These children were seen by their peers as roguish and less orderly. However, they were the ones who led improvisation into the common play and expanded it into a full sound story with movement and even a simple scene. This proved the importance of peer interactions, where movement was not trivial but rather "a form of knowing that was specifically expressed through bodily movement and activity in the combination of song, movement and actions" (Kalinde \& Vermeulen, 2016, p. 5).

In the sounded story telling participants produced the most non-conventional sounds, noises and tones, and used their voices in the manner of indigenous people. They created narratives with many sound effects, which spoke about children's views of life and the world. In their singing inventions, children sometimes used melismas, which only occur exceptionally in Slovene folk music. It is possible to assume that they

\footnotetext{
${ }^{1}$ The first stage represents »synchronisation « (a fundamental component that deals with synchronisation to a beat). The second stage is "embodied attuning" which concerns the relation between body movements and musical features to more complex than a basic beat - e.g. harmony, melody, rhythm, tonality, timbre) (Leman, 2007).
} 
subordinated their action to the common sensation about an extra-musical happening and shaped their inventions according to some old compositional rules which they had never learned or performed before. Short pentatonic melodies and exclamations and the improvised song in the Dorian mode point to an archaic origin, only found in a few Slovene religious songs or Christmas carols that can be traced back to the time of the first Slovene protestant hymnbooks (Kumer, 1975). So, how come we found such melodies in an urban primary school? We believe that such music making can (also) be attributed to a completely relaxed state and the immersion of all children in the same activity and, even more so, to the good relations that gradually developed among children in the group. In a study, MacDonal et al. (2006) proved that communication, verbal and non-verbal, such as musical communication, was more successful when performers were also good friends outside their work environment. This means that connections with others and good knowledge of their personalities increases the possibilities of a successful improvisation.

In contrast to our findings, which indicate that children reached a fully personal musical expression through metrically organised rhythmic contents, a study by Kratus (1989) showed that children between the ages of five and eleven develop melodic patterns sooner and more accurately than rhythmic ones. Children involved in our study showed enough skills and originality to be able to express their ideas in sound stories in the way that shows that they were satisfied with themselves. On the other hand, Brophy (2005) believes that improvisation with 8 and 9 year old children are organised more systematically than with 7 year olds due to a poorer development of musical skills in older children as compared to the younger ones. In his study, children improvised less reliably in a steady pulse. The same happened in a study by Kiehn (2007). However, Kiehn (ib.) showed that children demonstrated less sense of phrasing and shaping musical motives and that the latter only developed as a surprise arising from the contrasting of musical ideas. Our study revealed quite the opposite: while children did have to learn to shape musical parameters on their own, they did so right from the beginning, with a great deal of musicality in numerous dynamical and articulation variants and with a clever selection of accompanying sounds and noises. Singing improvisations were not sung in the major scale, as we would expect, given the fact that they are predominantly familiar with children songs in major. However, during the final lessons, children incorporated these improvisations, either whole or the selected motives or parts with changed lyrics, into larger musical forms. Most importantly, the collected materials allow us to definitely conclude that, with their free singing outside any tonalities, the singers always reached the sensations of others.

Children develop social competences of a great value when they are involved in symbolic play with folk music elements in the improvisational mode.

The participants in the study were active in many domains: in the cognitive domain, when they performed aesthetically shaped musical material; in the emotional domain, when they demonstrated emotions and recognised the sensations of others, responding 
in non-verbal musical communication; in the psychomotor domain, when they expressed their emotions triggered by music with movements; and in the social domain, when they observed, imitated, entered into a dialogue in non-verbal communication, etc. Music affected them holistically, which is precisely why they also responded to it in a holistic manner. Plato and Aristotle (in Elliott, 2005) already claimed that music has a formidable social and ethical power, since it is able to restore, repeat and look for certain emotions in people. They suggested that the use of musical parameters be restricted to those with positive ethical effects.

Our lessons, which were based on children's folk music, showed the importance of establishing a balance between an individual's challenge and the reaction of everybody else. If everybody involved creates in a state of flow, as defined by Csikszentmihalyi (1990), the sensations of co-existence contribute to the confirmation of every single contribution to the final (musical, dance) product (MacDonald et al., 2006). Consequently, the level of creativity improves, particularly in case of group work, when the flow, and the creative achievement, is considerably higher than in case of an individual (ib.). In this kind of play, fears of making errors vanish and feedback on the performance is given by peers in a reflective discussion, both leading to an improved awareness about individual musical elements (ib.). The study confirmed that children's folk music in the form of improvisation had the same effect, but only after children had explored the dimensions of music to their limits and started to plan musical products which were more process oriented. Thus, participants developed creative behaviour: firstly, in showing complete freedom of expression with musical parameters, secondly, in their desire to explore the sound material, and thirdly, by departing from everything usual and returning to the roots of their own music, shaping it with new experience, knowledge and ideas about the interpretation of "sound effects, dances, which are also part of this socio-dramatic arts play" (Niland, 2007).

It is also confirmed that children prefer other children whose favourite songs are familiar to them (Soley \& Spelke, 2016); the effect is known as shared knowledge. It suggests that young children have an outstandingly selective sensitivity to shared cultural knowledge. It may be a powerful determinant of children's social preferences, both because it underpins effective communication and because it is conveyed by others through social interactions and therefore can serve as marker of social group identity. This happens especially in groups making music as it was a case in our study, when we used the elements of multisensory aspect of music (as it is also a case in Orff Music Therapy). The activities were not restricted to the acoustical features of music - for example, letting marbles roll along a metallophone into a hand drum or playing a drum so that balls will fly off it (Voigt, 2003). They also helped to encourage children to step out of "being wrong" or "playing correctly" ... and to start exploring sounds in improvisation.

Hence, making music together, i.e. within group improvisation, is an approach to music which equally develops "the soul, the spirit and the body" (Roche Marquez, 2001), as well as social competences, described by Gardner in his theory on multiple 
intelligences as intra- and interpersonal intelligences (Gardner et al., 2009). However, communication within the constructive music-making depends primarily on a feeling of safety which the participants acquire in an emotionally stable environment where they are accepted unconditionally, and later, when they are faced with clear, rationally grounded requirements, which are indispensable in order to develop the ability of coexistence in a group.

\section{Conclusion}

Providing a detailed description of holistic music education based on elements of children's folk music, the present study points to the fact that the participating children had yet to grasp the basic characteristic of folk music, i.e. spontaneity in its creation and performance, through the learning process. Short, simple melodies and motives close to a child's everyday life were often regarded as a tedious learning content. Only after several months of work, using the holistic method of music teaching, children were able to develop these contents into a breeding ground for new ideas and original (trans) formation of musical elements on the path to non-verbal musical communication. Through symbolic play, children abandoned the conscious and well-considered way of going about music and experienced music in its creation - music which was abundant in its expression and perfected.

Based on results, a question arises as to the way in which music teachers could give children opportunity for spontaneous music making within the very restricted school time available. And last but not least, how can they even arouse their interest in such activities, since very often children have a more or less negative attitude towards folk tradition, regarding it as something that belongs in a museum? How is it possible to show children and young people that folk music is alive? The study reveals and suggests the way to give meaning to children's folk music and allow it, through children themselves, to develop into a gathering of deeply connected creators - singers, dancers, actors, musicians - even if stones or twigs are the "only" instruments they use.

\section{References}

Biber, K. (2016). The Effects of Folk Dance Training on 5-6 Years Children's Physical and Social

Development. Journal of Education and Training Studies, 4(11), 213-226 https://doi. org/10.11114/jets.v4i11.1820

Brophy, T. S. (2005). A longitudinal study of selected characteristics of children's melodic improvisations.

Journal of Research in Music Education, 53(2), 120-133 https://doi.org/10.2307/3345513

Cankar, I. (2012). Moje življenje [My Life]. Mladinska knjiga.

Chronopoulou, E., \& Riga, V. (2012). The Contribution of Music and Movement Activities to Creative 
Thinking in Pre-School Children. Creative Education, 3(2), 196-204 https://doi.org/10.4236/ ce.2012.32031

Csikszentmihalyi, M. (1990). Flow: The Psychology of Optimal Experience. Harper and Row.

Elliott, D. J. (2005). Musical Understanding, Musical Works, and emotional Expression: Implications for Education. In D. K. Lines (Ed.), Music education for the New Millennium (pp.112-122). Blackwell Publishing Ltd. https://doi.org/10.1111/j.1469-5812.2005.00100.x

Frid, E., Bresin, R., Alborno, P., \& Elblaus, L. (2016). Interactive Sonification of Spontaneous Movement in Children - Cross-Modal Mapping and the Perception Qualities through Sound. Frontiers in Neuroscience, 10(521). doi: 10.3389/fnins.2016.00521

Gardner, H., Moran, S., \& Chen, J. (2009). Multiple intelligences around the world. Jossey-Bass.

Han, K., Marvin, C., \& Walden, A. (2003). Searching for an alternate way to identify young creative minds: A classroom-based observation approach. Assessment for Effective Intervention, 28(1-17). https://doi.org/10.1177/073724770302800201

Holcar, A., Borota, B., Breznik, I., Jošt, K., Kovačič, A., Lango, J., Mraz Novak, T., \& Sicherl Kafol, B. (2011). Učni načrt. Program osnovna šola. Glasbena vzgoja [Slovene Music Education Curriculum for Primary School]. Ljubljana: Ministrstvo za šolstvo in šport, Zavod RS za šolstvo. http:/www.mss.gov.si/fileadmin/mss.gov.si/pageupload/podrocje / devetletka/predmeti_obvezni/Glasbena:vzgoja_obvezni.pdf

Howard-Jones, P. A., Taylor, J. R., \& Sutton, L. (2002). The effects of play on the creativity of young children. Early Child Development and Care, 172(4), 323-328. doi.org/10.1080/03004430212722

Iversen, J. R., Patel, A. D., \& Ogushi, K. (2007) Nonlinguistic rhythm perception depends on culture and reflects the rhythms of speech. Language and Music as Cognitive Systems. University of Cambridge. http://mus.cam.ac.uk/CMS/fles/2011/1'/LMCS booklet 2007.pdf

Jungmair, U. (2003). Das Elementare. Zur Musik- und Bewegungerziehung im Sinne Carl Orffs. Mainz: Schott Musik International.

Kalinde, B. (2016). Fostering children's music in the mother tongue in early childhood education: A case study in Zambia. South African Journal of Childhood Education, 6(1) https://files.eric.ed.gov/fulltext/EJ1186995.pdf; https://doi.org/10.4102/sajce.v6i1.493

Kiehn, M. T. (2003). Development of music creativity among elementary school students. Journal of Research in Music Education, 51, 278-288. doi/10.2307/3345655

Kiehn, M. T. (2007). Creative Thinking: Music Improvisation Skills Development among Elementary School Students. Journal of Education and Human Development, 1(2), 1-13. https://pdfs.semanticscholar.org/deb3/5de77f227f8dcc5e9e22a83409d7162cd6a3.pdf; https://doi.org/10.2307/3345655

Kordeš, U. (2008). Fenomenološko istraživanje. In N. Koller-Trbović, \& A. Žižak (Eds.), Kvalitativni pristup u društvenim znanostima. Znanstveni niz 20 (pp. 55-73). Univerza u Zagrebu. Edukacijsko-rehabilitacijski fakultet.

Kordeš, U. (2009). The Phenomenology of Decision Making. Interdisciplinary Description of Complex Systems, 7(2), 65-77 /online/. http://indecs.eu/2009/indecs2009-pp65-77.pdf

Kratus, J. (1989). A time analysis of the compositional process used by children ages 7 to 11 . Journal of Research in Music Education, 37(1), 5-20. http://jrm.sagepub.com/content/37/1/5; https://doi.org/10.2307/3344949 
Kroflič, R. (2007). Vstop v kurikularne teorije. Izbrani pedagoški spisi [The Entry in Curricular Theories. Selected pedagogical documents]. Zavod Republike Slovenije za šolstvo.

Kumer, Z. (1975). Pesem slovenske dežele [The Song of Slovenian Country]. Založba Obzorja. Kumer, Z. (1977). Etnomuzikologija [Musical Ethnology]. Filozofska fakulteta Univerze v Ljubljani, PZE za muzikologijo.

Kunaver, D., Kumer, Z., \& Ložar-Podlogar, H. (1987). Pesmi in šege moje dežele [Songs and Customs of my Country]. Državna založba Slovenije.

Leman, M. (2007). Embodied Music Cognition and Mediation Technology. MIT Press. https:// doi.org/10.7551/mitpress/7476.001.0001

Linnvalli, T., Putkinen, V., Lipsanen, J., Houtilainen, M., \& Tervaniemi, M. (2018). Music playschool enhances children's linguistic skills. Scientific Reports, 8(8767). doi: 10.1038/ s41598-018-27126-5. https://doi.org/10.1038/s41598-018-27126-5

MacDonald, R., Byrne, C., \& Carlton, L. (2006). Creativity and flow in musical compositions: an empirical invetigation. Psychology of Music, 34(3), 292-306. https://doi. org/10.1177/0305735606064838

Medveš, Z. (2007). Vzgojni modeli v reformski pedagogiki [Educational models in reformatory pedagogy]. Sodobna pedagogika, 58/124(4), 50-69.

Morin, L. B. (2001). Cultivating music play: The need for changed teaching practice. General Music Today, 14, 24-29. https://doi.org/10.1177/104837130101400204

Niland, A. (2007). Musical Stories: Strategies for Integrating Literature and Musical for Young Children. Australian Journal of early Childhood, 32(4), 7-11. https://doi. org/10.1177/183693910703200403

Niland, A. (2009). The Power of Musical Play: The Value Play-Based, Child-Centered Curriculum in Early Childhood Music Education. General Music Today, 23(1), 17-21. https://doi.org/10.1177/1048371309335625

Orff, G. (1989). Key Concepts in the Orff Music Therapy. Shott.

Papalia, D. E., Wendoks Olds, S., \& Duskin Feldman, R. (2003). Otrokov svet [Child's World]. Educy.

Roche Marquez, E. M. (2001). Einige gedanken über die soziale Dimension des OrffSchulwerks. Orff- Schulwerk Informazionen, 65, 13-16.

Russ, S. W., Robins, A. L., \& Christiano, B. A. (1999). Pretend Play: Longitudinal prediction of creativity and affect in fantasy in children. Creativity Research Journal, 12, 129-139. doi:abs/10.1207/s15326934crj1202_5

Sangirogio, A. (2010). Orff-Schulwerk as Anthropology of Music. In G. Piazza (Ed.),

L'Orff-Schulwerk in Italia. Storia, esperienze e riflessioni (142-157). http://www. centrodidatticomusicale.it/images/stories/disp/sang/andrea sangiorgio orff-schulwerk as anthropology of music.pdf

Sangiorgio, A., \& Hennessy, S. (2013). Fostering children's rhythm skills through creative interactions: An application of the cognitive apprenticeship model to group improvisation. In A. de Vogt, \& I. Malmberg (Eds.), Eurepean perspectives on Music Education 2 - Artistry (pp.105-118). Helbling. 
Soley, G., \& Spelke, E.S. (2016). Shared cultural knowledge: Effects of music on young children's social preferences. US National Library of Medicine, 148, 106-116. https://doi. org/10.1016/j.cognition.2015.09.017

Sternberg, R. J. (2006). The Nature of creativity. Creativity Research Journal. 18(1), 8789. https://doi.org/10.1207/s15326934crj1801 10; http://lchc.ucsd.edu/mca/Mail/ xmcamail.2010 10.dir/pdfFlf9STmJn3.pdf

Tarnowski, S. M. (1999). Musical play and young children. Music Educators Journal, 86, 26-29. https://doi.org/10.2307/3399573

Voigt, M. (2003). Orff Music Therapy - an Overwiev. Voices: A World Forum for Music Therapy. http:/www.voices.no/mainissues/mi40003000129.html https://doi.org/10.15845/voices. v3i3.134

Yin, K. R. (2004). The Case Study Anthology. SAGE Publications, Inc.

\section{Konstanca Zalar}

Department of Music

Faculty od Education

University of Ljubljana

Kardeljeva ploščad 16, 1000 Ljubljana, Slovenia

konstanca.zalar@pef.uni-lj.si 


\section{Doživljaj narodne glazbe kod djece}

\section{Sažetak}

Velik je dio kulture svakog naroda narodna glazba koja predstavlja improvizacijske sposobnosti pojedinaca i grupa. Unatoč svim promjenama, ona nesporno održava sve karakteristike glazbenih parametara kao nasljeđivanje prošlih vremena. $U$ studiji koja je provedena sa skupinama djece u dobi od šest do osam godina, zanimalo nas je kako se dječja igra može oblikovati folklorno-glazbenim elementima. Sposobnosti grupnoga glazbenog stvaralaštva proučavane su kroz aktivnosti holističkoga glazbenog obrazovanja, što uključuje - baš kao i dječju narodnu glazbu - pokret, pjevanje, sviranje dječjih instrumenata i aktivnosti kreativnoga rada s različitim glazbenim elementima. Istraživanje je osmišljeno kao fenomenološka studija. Ta nam je metoda omogućila prikupljanje podataka koji su pružili dublji uvid u način na koji se sudionici osjećaju dok koriste elemente narodne glazbe. Rezultati pokazuju da se djeca, u suprotnosti s osnovnom činjenicom spontanosti u narodnoj glazbi, tek trebaju naučiti igrati s elementima narodne glazbe u glazbenom jeziku. Ritam se činio najjasnijim glazbenim parametrom, unutar kojeg su sudionici prvi put osjetili velik improvizacijski potencijal. Također smo otkrili da u igranju s elementima narodne glazbe postoji velika vrijednost razvoja socijalnih kompetencija.

Ključne riječi: glazbeni jezik; grupno stvaranje glazbe; fenomenologija; socijalne kompetencije 